\title{
Towards a Feminist Global Trade Politics
}

DOI:

10.1080/14747731.2020.1779966

\section{Document Version}

Accepted author manuscript

Link to publication record in Manchester Research Explorer

\section{Citation for published version (APA):}

Hannah, E., Roberts, A., \& Trommer, S. (2020). Towards a Feminist Global Trade Politics. Globalizations. https://doi.org/10.1080/14747731.2020.1779966

\section{Published in:}

Globalizations

\section{Citing this paper}

Please note that where the full-text provided on Manchester Research Explorer is the Author Accepted Manuscript or Proof version this may differ from the final Published version. If citing, it is advised that you check and use the publisher's definitive version.

\section{General rights}

Copyright and moral rights for the publications made accessible in the Research Explorer are retained by the authors and/or other copyright owners and it is a condition of accessing publications that users recognise and abide by the legal requirements associated with these rights.

\section{Takedown policy}

If you believe that this document breaches copyright please refer to the University of Manchester's Takedown Procedures [http://man.ac.uk/04Y6Bo] or contact uml.scholarlycommunications@manchester.ac.uk providing relevant details, so we can investigate your claim.

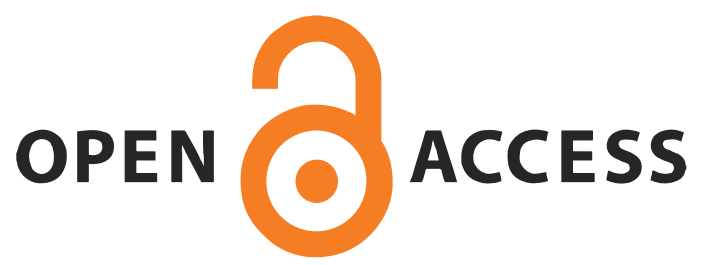




\title{
Towards a Feminist Global Trade Politics
}

Published in Globalizations

Erin Hannah (University of Western Ontario), Adrienne Roberts (University of Manchester) and Silke Trommer (University of Manchester)

ORCID (Hannah): 0000-0001-8062-6035

ORCID (Roberts): 0000-0002-0204-5152

ORCID (Trommer): 0000-0001-9719-8065

Twitter (Hannah): @ErinHannah2

Twitter (Roberts): @DrAdrienneRob

Twitter (Trommer): @SilkeTrommer

Corresponding author: Erin Hannah

\begin{abstract}
Socially progressive globalisation in a post-neoliberal era must recognize the centrality of gendered and other social hierarchies to the deeper workings of the global political economy and actively seek to dismantle them. In practice, this involves: (i) redefining the purpose of global trade in ways that value, prioritize and support progressive forms of social reproduction; (ii) centering trade policy on a holistic understanding of the economy; and (iii) democratizing global trade relations. In this article, we outline an approach to understanding global trade rooted in feminist International Political Economy, take stock of a range of existing gender and trade initiatives to show where progressive reforms have been taken and where these fall short, and make concrete suggestions on how to formulate trade policies in line with globalist, feminist prerogatives.
\end{abstract}

KEYWORDS: Gender; trade; feminist political economy; global political economy; social reproduction

Funding details: This work was supported by the Canadian Social Sciences and Humanities Research Council (SSHRC) Insight Development Grant 430-2018-00349 and the SSHRCESRC Knowledge Synthesis Grant 872-2018-0012

\section{Biographical Notes}

Erin Hannah is Associate Professor and Chair of the Department of Political Science at King's University College at the University of Western Ontario, Canada.

Adrienne Roberts is Senior Lecturer in the Department of Politics at the University of Manchester, UK.

Silke Trommer is Senior Lecturer in the Department of Politics at the University of Manchester, UK.

\section{Introduction}


In 2015 United Nations (UN) experts expressed concern about the adverse impacts of free trade and investment agreements on 'the rights to life, food, water and sanitation, health, housing, education, science and culture, improved labour standards, an independent judiciary, a clean environment and the right not to be subjected to forced resettlement' (OHCHR, 2015). Their report points to the potential for trade agreements to undermine civil, cultural, economic, political and/or social rights enshrined in legally binding instruments, including commitments made to support gender equality. It notes that, 'undoubtedly, globalization and the many Bilateral Investment Treaties and Free Trade Agreements (FTAs) can have positive but also negative impacts on the promotion of a democratic and equitable international order, which entails practical international solidarity' (OHCHR, 2015). These are key concerns for feminist scholars, as well as a growing number of Non-Governmental Organizations (NGO), states and international organizations.

In our contribution to this Special Issue on post-neoliberal 'reglobalization', we explore the gendered dynamics of trade and chart a pathway to a feminist trade politics that is more progressive than existing approaches, even where gender concerns are present. This is an important endeavour since trade policy is often presented as gender-neutral - targeting neither men nor women - and policy-making is viewed as the realm of experts. Yet, as the UN report suggests, trade can produce equitable and inequitable outcomes globally. Indeed, feminist research has extensively documented how trade impacts on people in their multiple roles as workers, producers, consumers (of goods and services), providers of unpaid care work, and more. Given that existing gender norms and power relations shape one's relationship with these activities, the outcomes of trade policy are deeply gendered, as well as differing along the lines of class, race, ethnicity, age, ability, and more (van Staveren, Elson and Çağatay, 2007; Roberts, Trommer and Hannah, 2019). The impacts of trade also vary depending on country context.

It has been well established that women are among those most negatively affected by the globally integrated trading system that has been a defining feature of neoliberal globalisation (Roberts, Trommer and Hannah, 2019). Yet, like the editors of this Special Issue, we do not believe that deglobalization will necessarily bring about a more equitable global order, irrespective of whether this notion refers to the undoing of all or most forms of international cooperation, or to the abandonment of the multilateral trading system in favour of bilateral trade relations whereby the most powerful states are best able to secure their interests. Nonetheless, for reasons we elaborate below, socially progressive globalization necessarily spells the end of neoliberal economic globalisation - or what some call 'hyper-globalisation' (Rodrik, 2011) - where the elimination of obstacles to trade and financial flows in the name of economic growth constitutes an end in itself. Our position is that globalization ${ }^{1}$ can take multiple forms and socially progressive, post-neoliberal reglobalization must prioritise social goods such as equality, progressive social reproduction, and sustainability over economic growth.

At the same time, however, we are wary of the editors' suggestion that the inequalities of neoliberal globalization can be addressed by re-regulating or re-embedding liberal ideals within the political sphere (Bishop and Payne, 2019; 2020). As we demonstrate in detail, although this may lead to some progressive changes, it risks perpetuating gender-based and other hierarchies that operate within the economic and the political spheres, and in the so-

\footnotetext{
${ }^{1}$ We understand globalization to refer to any historical process marked by the existence of economic, political, social and cultural exchanges among different political communities across the world.
} 
called private sphere of the household. It also reproduces a false distinction between these spheres. This distinction fosters a narrow understanding of the social relations that constitute the economy and leads to forms of policy-making that are ultimately unable to address structural inequalities.

In the following section, we outline a feminist International Political Economy (IPE) approach to the study of global trade that elucidates how gendered and other power relations shape and are shaped by trade relations at multiple sites and scales. This offers an alternative theoretical vantage point to more liberally-oriented approaches that focus on greater choice and opportunity in the 'public' sphere (i.e. the economy, politics etc.) (Bishop and Payne, 2020), which is, either implicitly or explicitly, analytically separated from the 'private' sphere of the household. Building on longstanding feminist critiques of liberal thought and economic practice, we seek to place the study of power in its various dimensions (economic, political, social) in the centre of the analysis and call for a radical rethinking of economic policy-making.

Using our feminist lens, in section two we explore a range of gender and trade initiatives pursued in trade governance in recent years. We identify policy initiatives that begin to consider the social basis of economic relations, including how trade policy affects women's (and men's) multiple roles in society and in the economy. However, we also argue that a number of factors limit the progressive potential of existing initiatives, including an adherence to a narrow understanding of economic growth as the primary purpose of trade, a limited understanding of how trade impacts on individuals, households and communities, and a failure to develop meaningful forms of democratization. In section three we outline concrete suggestions for how to formulate trade policies that, among other things, help undermine structural inequalities within the global political economy, prioritize progressive forms of social reproduction, infuse global trade politics with a more holistic understanding of economic activity, and democratize trade policy-making.

\section{Toward a Feminist IPE of Trade}

Trade policy reforms under neoliberal globalization have come with a deepening of genderbased inequalities in many areas. This is evidenced, for instance, in increases in the genderbased pay gap that have accompanied the incorporation of women into export-producing industries. Comparative studies have shown this to be the case in many countries where lowpaid female labour constitutes a form of competitive advantage (Busse and Spielmann, 2006). Where trade liberalization increases the cost of food imports, this is disproportionately felt by the poorest households and women who tend to have less access to and control over income while also being primarily responsible for food purchase and preparation (Siddiqui, 2009).

Women, alongside certain racial and minority ethnic groups, are also over-represented among public-services users, partly because they tend to take on greater responsibility for care work. In most countries, they also make up the majority of workers in the health, social work and education sectors. This means that, when trade agreements liberalize public and essential services, these groups are disproportionately affected as users and workers (Williams, 2007). At the same time, loss of government revenue resulting from trade-policy reform - e.g. through tariff reductions - may have knock-on effects on public-services users, as public services fall prey to government cut-backs (Elson, Grown and Cağatay, 2007). If the gendered nature of public-services usage and the provisioning of paid and unpaid care are not 
taken into account, trade liberalization also risks decreasing the amount of care work performed overall.

While feminist scholars have been documenting the gendered impacts of trade for several decades (Williams, 2013), we have only recently witnessed a surge of interest on the part of a number of states, international organizations, NGOs and others to introduce gender and trade initiatives in global governance. Surveying different gender and trade initiatives offers us an entry point into thinking about one key question that motivates this Special Issue: what would a socially progressive form of globalisation actually entail in practice?

From our perspective, the language of 're-regulating' or 're-embedding' economic relations used by the editors of the Special Issue, even where these are conceived as being 'postneoliberal', has limited potential for radical transformation. Indeed, going back to John Ruggie's (1982) work, the aim of embedded liberalism is to combine global trade liberalization with domestic interventionism. The goal of the former is to increase wealth within the global economy, while the goal of the latter is to achieve economic stability within nation-states. However, the costs of creating domestic stability in the core capitalist countries were ultimately offloaded onto poorer countries (Muzaka and Bishop, 2015), increasing inequalities globally. Moreover, in a key passage, Ruggie claims that attempts to combine global liberalization and national interventionism necessarily led to the 'geographical, sectoral and institutional concentration' of trade and financial flows of the 1950s and 1960s (Ruggie, 1982: 400). Geographically, embedded liberal trade became concentrated among the countries that had designed the rules of the embedded-liberal trading system. This trade increasingly took place within the same economic sectors and among the same corporations. For Ruggie, this meant that the gains from trade were increasingly directed towards a select number of individual sectors and firms, which had the effect of increasing economic inequalities (Ruggie, 1982). Recalling this aspect of Ruggie's argument offers an important point of caution: even where domestic 'post-neoliberal' interventionism accompanies reglobalisation, this may still cement and reproduce inequalities globally.

A separate critique of the language of embeddedness comes from feminist scholarship, which has long criticised liberalism for perpetuating a false distinction between the public and the private spheres and for ignoring inequalities in the latter. In their work, political economists such as Ruggie and Karl Polanyi (who Ruggie (1982: 387) credits with developing the distinction between 'embedded' and 'disembedded' economic orders) analytically separate 'the economic' from 'society' (which includes political society and the family). This risks obscuring both the social relations that fundamentally constitute the economy and the hierarchical power relations that constitute society (Ferber and Nelson, 1993). As Nancy Fraser (2014: 544) writes with respect to Polanyi:

Preoccupied exclusively with the corrosive effects of commodification upon communities, it [The Great Transformation] neglects injustices within communities, including injustices, such as slavery, serfdom and patriarchy, that depend on social constructions of labour, land and money precisely as non-commodities. Demonizing marketization, the book tends to idealize social protection, as it fails to note that protections have often served to entrench hierarchies and exclusions.

While Polanyi has provided an important contribution to critical political economy, we join Fraser in her wariness of the notion of 're-embedding', precisely because it fails to capture 
adequately the extent to which 'the economic' and 'the social' are themselves imbued with hierarchies. In so doing, it risks reproducing socially constructed injustices.

Building on these observations, we suggest that a feminist IPE perspective is necessary in order to elucidate how gendered and other power relations shape and are shaped by trade relations at multiple sites and scales. In particular, we deploy and extend three key analytical insights of feminist IPE scholarship, all of which are interrelated and have important implications for imagining a more progressive future global trading regime.

First, feminist IPE acknowledges the operation of structural inequalities in the global political economy, showing how existing gender norms and power relations shape one's participation in the economy at multiple sites and scales (Bedford and Rai, 2010; Elias and Roberts, 2018). In terms of trade, this explains, inter alia, why export promotion that relies on low-paid feminized labour tends to increase the gender pay gap, and why service liberalization tends to affect women and certain racial and minority ethnic groups most negatively. As Mariama Williams, a pioneer in gender research on trade, explains: 'the work is very clear from feminist economics ... Trade liberalisation does not create structural gender inequalities, but it may create conditions that can either enhance women's economic situation, or exacerbate their pre-existing gender inequality and bias' (Williams, 2019). Put differently, as trade policies affect people in multiple ways, they may either undermine or reproduce existing structural inequalities. As we will demonstrate below, many of the existing gender and trade initiatives remain committed to economic growth as the main purpose of trade and seem to assume that integrating women into existing economic structures will improve gender outcomes. In contrast, we advocate for the need to document better and dismantle actively structural inequalities. This involves, among other things, prioritizing progressive forms of social reproduction in trade theory and policy-making.

A second and related feminist insight is that there is a need to disturb the distinction between the economy and society perpetuated by liberalism in all its forms. One way that feminists have done this is by analytically centering the relations of social reproduction that underpin all forms of economic activity. Within feminist IPE, most definitions of social reproduction relate to at least three aspects: the biological reproduction of the species, which includes social constructions of motherhood and the conditions under which this work is performed; the reproduction of the labour force (including subsistence, education and training); and the reproduction and provisioning of caring needs (Bakker, 2007: 541). Others add the reproduction of culture and ideology (Hoskyns and Rai, 2007) or, at a more abstract level, the reproduction of the conditions of social production in their totality, which includes the basic structures of production (Edholm, Harris and Young, 1977). From our perspective, the important point to emphasize is that social reproduction takes place in different sites and spaces including the home and the community, through the state (i.e. in the health, social and education sectors), and in the market (including via paid labour in the formal and informal sectors). The point is not to reify a distinction between production and its outside - or 'the economy' and 'society' - but rather to show how the 'production of goods and services and the production of life are part of one integrated process' (Luxton, 2006: 36).

Bringing this insight into analyses of trade draws attention to economic relations and impacts that are ordinarily eclipsed from the purview of global trade, despite the fact that they are inherently part of global trade relations. This means, for example, that trade theory and policy analysis need to consider the impact of trade on communities and people in their multiple roles as producers, workers, consumers (including consumers of public services), carers, and 
more - as well as the broader ecological framework. Starting from the centrality of social reproduction further leads us to follow feminist IPE scholars in insisting that 'the production of people, meeting human needs, and fostering well-being should be the driving force of economics', rather than production for the purposes of economic growth and capital accumulation (Luxton, 2018: 37; see also Rai and Waylen, 2014). A crucial part of fostering well-being further involves a commitment to environmental sustainability.

Finally, feminist IPE provides a third analytical insight: it is essential to acknowledge heterodox and feminist knowledge about global trade and those political and societal actors that represent it as valuable and legitimate in trade policy processes. Orthodox knowledge about global trade cements the idea that open markets and free trade are desirable ends in themselves (Eagleton-Pierce, 2016). It is rooted in modernist and positivist dedications to 'rational economic man', whose self-interested, calculating and competitive behaviour is supposed to act as a model for all human decision-making (Folbre, 2001; Ferber \& Nelson, 2003). In legal terms, this logic is locked in through binding and enforceable disputesettlement mechanisms in trade agreements. In political terms, it performs a gate-keeping function in terms of who is considered a legitimate participant in trade policy-making (Hannah, Scott and Trommer 2015). Feminist scholars have criticized this locking-in of market principles because it locks out the rights of people to participate in democratic decision-making and privileges the rights of capital above those of the population (Bakker and Gill, 2006). Feminist IPE instead centres the experiences and voices of people, particularly women and marginalized groups, above open-market and free-trade prerogatives. Inclusiveness, the recognition of the intersectional dimensions of inequality, public transparency and accountability are key feminist concerns for global policy-making (Prüg1 and True, 2014) that go against the masculinized, elitist and legalized trade orthodoxy.

\section{The (False) Promise of Existing Gender and Trade Initiatives}

Below, we evaluate existing gender and trade initiatives using the three analytical insights outlined above. Elsewhere, we surveyed global-policy practice in the field of gender and trade. Using total population sampling, we identified 77 initiatives launched since 1991 and coded them along 32 dimensions (Hannah, Roberts and Trommer, 2018). In this section, we assess four exemplary types of gender and trade initiatives emerging from our typology: women's entrepreneurship programmes, the World Trade Organization (WTO) Declaration on Trade and Women's Economic Empowerment, gender chapters in FTAs, and genderbased impact assessments. For each type of initiative, we ask the same questions: What is the overarching purpose of global trade? Does it recognize the centrality of structural gender inequalities to the global economy and seek actively to dismantle them? Does it adopt a narrow or broad understanding of economic relations? Does it further the democratization of global trade relations? We begin our analysis with a brief overview of these initiatives before assessing their promise of advancing gender equality in and through trade.

Currently, the most popular type of gender and trade initiative in global governance is support for women's entrepreneurship in the Global South (Hannah, Roberts and Trommer, 2018). The International Trade Centre (ITC)'s 'SheTrades' initiative aims to connect one million women entrepreneurs to global markets by 2021. 'Aid for Trade' initiatives that are often part of official development assistance (concessional government aid designed to promote the economic development and welfare of developing countries) are now explicitly mandated for gender equality (WTO and OECD, 2019). Significant resources have also been 
dedicated to various micro-interventions in support of women who participate in cross-border trade. These interventions often aim to help women grow their enterprises through the provisioning of loans and/or financial literacy education, and to develop the knowledge and skills necessary to engage in trade.

Within this broader context, 121 WTO member-states and observers signed the WTO Declaration at the 2017 ministerial conference. It marks the first time WTO members have signalled a willingness to engage with what was previously seen as a human-rights issue. Although key members - notably India and the United States - remained outliers, the declaration raised the possibility that multilateral trade governance could connect with global economic and social agendas (Hannah, Scott and Wilkinson, 2018). A best-endeavour initiative by like-minded members, the declaration launched a fact-finding agenda intended to bolster the role of women in trade, particularly in new areas such as e-commerce. The Work Programme, in particular, commits signatories to seven multi-stakeholder workshops aimed at economically empowering women and integrating them into global value chains (WTO, 2017).

Outside of the multilateral system, there are currently four FTAs with specific gender chapters, and one with proposed text. They are: the Chile-Canada FTA, the Chile-Argentina FTA, the Uruguay-Chile FTA, the Canada-Israel FTA and the EU-Chile FTA. While there are numerous trade agreements containing gender provisions (Monteiro, 2018), gender chapters are the most recent and far-reaching trend in incorporating gender concerns into trade agreements. Like the WTO Declaration, gender chapters aim at advancing gender equality and increasing the participation of women in trade. They do so by affirming the importance of incorporating a gender perspective in international trade and commit parties to the FTA to redressing trade-related gender discrimination.

Alongside these legal texts, policy-makers have begun assessing the gendered impacts of trade policy. In 2017 Canada committed to applying Gender Based Analysis Plus (GBA+) to all federal budget items, including new FTAs. Canada has conducted one initial GBA+ of the Canada-Mercosur FTA to date (Global Affairs Canada, 2019). The European Union (EU) is also increasingly including a gender analysis under its ordinary Sustainability Impact Assessment procedure for FTAs - for example, for the EU-New Zealand FTA (European Commission 2019). The United Nations Conference on Trade and Development (UNCTAD) has developed a methodology for gender-based impact assessments, named the Trade and Gender Toolbox (UNCTAD, 2017). It consists of four main components: (1) descriptive analysis of gender inequalities and the economic context of the country at stake; (2) quantitative analysis of the expected consequences of trade policies on the economy (in terms of exports, gross domestic product, sectoral labour demand) and particularly on women's participation in the economy; (3) a checklist for gender-sensitive accompanying measures and monitoring indicators; and (4) a 'Trade and Gender Index' treating female employment and gender gaps as indicators of gender inequalities in the workplace (used for withincountry analysis over time).

Existing initiatives are welcome to the extent that they move towards acknowledging the links between social reproduction and trade policy, adopt a more holistic understanding of the impacts of trade and recognize that women's groups hold knowledge about global trade that is relevant for policy-making. However, they also risk cementing and even exacerbating social and economic inequalities in ways we set out below. 


\section{(Not) prioritizing social reproduction over economic growth}

While some existing gender and trade initiatives show awareness of social reproductive activities, they generally do not abandon their commitment to economic growth as the purpose of global trade. Those initiatives most wedded to economic liberalism, such as ITC's 'SheTrades' and the WTO Declaration, focus on integrating women into a neoliberal economic model and a technocratic trade regime that prioritizes economic growth. More progressive initiatives, like the UNCTAD gender toolbox or the Argentina-Chile and Uruguay-Chile FTAs, are better attuned to how trade policies affect women's participation in the economy and outline domestic policies to mitigate the negative impacts of trade on workers, public-services users, carers, and more. Nonetheless, all gender chapters are standalone and generally not enforceable through dispute settlement (Larouche-Maltais and MacLaren, 2019). This means that their provisions find no application in clauses pertaining to trade in goods, trade in services, trade-related intellectual property rights (IPRs), investment protection, government procurement, micro, small and medium-sized enterprises (MSMEs), and e-commerce. The impacts of FTAs in these areas have been shown to exacerbate preexisting gender inequalities (Roberts, Trommer and Hannah, 2019). This raises legitimate concerns that gender and trade initiatives in their present form constitute minor policy adjustments that appear to prioritize social goals, but in effect serve as window-dressing, further entrenchment of neoliberal trade.

The disagreement playing out among WTO member-states over the WTO Declaration shows how gender and trade initiatives may reproduce, rather than undermine, existing conflicts and the inequitable power relations of the global trading system. The declaration is designed to push forward liberalization and longstanding items on the WTO agenda, including: the removal of trade barriers, trade financing, public procurement, MSMEs and trade facilitation. By contrast, non-signatories in the WTO claim the key to achieving gender equality lies in fulfilling the abandoned Doha Development Agenda, including the liberalization of agriculture through the elimination of domestic subsidies and the fair use of flexibilities such as the special-safeguard mechanism and public stockholding (Mlumbi-Peter, 2019). Proponents on both sides of the argument criticize what they see as the other side's instrumentalisation of the gender and trade nexus in order to push through their pre-existing interests in multilateral negotiations. The distribution of expected gains is not explicitly discussed. Instead, it is assumed that either state or market forces will assure women benefit from the reforms, without recognition of the fact that unequal gendered power relations persist in both spheres, as we explained above.

\section{(Partially) considering the multi-faceted impacts of trade policy}

The most progressive potential of existing gender and trade initiatives lies in a general acknowledgement that women feel the impacts of trade policy in their multiple roles in society. For example, the EU's proposed text for a gender chapter in EU-Chile acknowledges that 'trade liberalisation may affect men and women in different ways as workers, producers, traders or consumers' (European Commission, 2018). Other gender chapters recognize the importance of strengthening 'women's enhanced participation in the labour market and their economic independence and access to, and ownership of, economic resources' (Canada-Chile Art N bis-01.5), while Argentina-Chile adds access to 'decent work' to this list (Art. 15.1.4). Canada's GBA+ process for gender-based impact assessments includes a range of intersectional concerns, paying attention to relations based on race, religion, indigenous heritage, socio-economic status, and more (Government of Canada, 2018). The UNCTAD 
gender toolbox points to the need to assess whether export-promotion policies include support for childcare and whether reductions in public expenditures and increases in taxation affect public-services access and the burden of care work (UNCTAD, 2017: 28).

However, there is no coherent or systematic approach to embedding a broad understanding of economic activity in trade policy, owing to the fact that social reproduction remains (at best) a second-order concern for trade policy-makers. This limits well-intentioned approaches. For example, Canada's GBA+ has not been applied to patterns of consumption, public-services access or unpaid care work. The UNCTAD gender toolbox does not consider the intersection of proposed trade policies and pre-existing social and economic hierarchies. Moreover, although gender-based impact assessment and monitoring can be useful in order to identify how trade policy can be combined with appropriate social policy to work to reduce gender inequality, the practice can often be different. Impact-assessment exercises are mainly used to legitimate trade-policy choices in the public debate (George, 2015), rather than to mitigate the adverse anticipated, or demonstrated, effects of trade policies, especially as these impact on consumption, relations of care, leisure time, and so on (Roberts, Trommer and Hannah, 2019; Hannah, Roberts and Trommer, 2018).

At the same time, many entrepreneurship initiatives and the WTO Declaration focus exclusively on the benefits of entrepreneurship from the perspective of employment and income, limiting their efforts to integrating women into existing economic relations. On the one hand, the support for women-owned SMEs is much needed in a context where they are among those businesses most negatively impacted by import competition under trade liberalisation (Gender and Development Network, 2017: 4-5). However, empowering women through entrepreneurship also requires a consideration of the effects this has on their working conditions and domestic obligations, ensuring that entrepreneurship is not conflated with unpaid and precarious work that increases the double burden on women (Roberts and Zulfiqar, 2019). This needs to be accompanied by attempts to bring about broader structural change since women are more likely to choose entrepreneurship because of poverty, lack of labour market opportunities, discriminatory property and inheritance laws, and social norms that limit their mobility and assign them primary responsibility for care work (Jamali, 2009; Vita, Mari and Poggesi, 2014).

A similar point can be made about achieving women's economic empowerment through ecommerce and digital trade, which is a popular focus of many initiatives. Treating the digital economy as a panacea for 'inclusive economic growth' and women's economic empowerment will cement existing structural inequalities if policy initiatives are not aimed at ensuring access to connectivity for women and other vulnerable groups in the so-called 'digital divide' (ITC, 2017). There are also concerns regarding corporate power in the field of digital trade and e-commerce as the inclusion of women-owned MSMEs in markets dominated by corporate giants like Amazon and Google is unlikely to yield significant benefits to vulnerable populations (James, 2019).

\section{(Not) democratising trade politics}

While some initiatives recognize that women's groups hold valuable knowledge of global trade, they fall short of prompting further democratization of trade policy formation.

Stakeholder consultation is a common mechanism across all gender and trade initiatives; yet there is no indication that this means meaningful participation of civil society and women's 
groups in the decisions related to the formulation, implementation, monitoring, and/or impact assessment of trade policy.

Despite campaigning since the Uruguay Round and before, civil society organizations, especially women's organizations, were not consulted in the design and execution of the WTO Declaration. Indeed, 164 women's groups and allied NGOs opposed the declaration because it 'appears to be designed to mask the failures of the WTO and its role in deepening inequality and exploitation' (Our World is Not for Sale, 2017). Some consider the declaration to be a 'Trojan horse' for new issues such as e-commerce, MSMEs and investment protection (Bissio, 2017). Others suggest that the 'proposals on gender, small and medium enterprises, [and] facilitating investment for development belie the determination to abandon [the] promises of a Doha Development Round, with negative impacts on billions of women' (Kelsey, 2017). These criticisms are, in part, reactions to the fact that civil society voices have been marginalized and that the declaration upholds existing trade orthodoxy. This means that the prospects for the work arising from the declaration to achieve gender equality and minimize the adverse impacts of trade policy on women and other vulnerable populations are grim.

\section{The Way Forward}

From our perspective, a progressive reform of the global trade regime requires at least three interrelated moves that map on to our three analytical insights. First, it requires redefining the purpose of global trade in a way that de-prioritizes economic growth and supports progressive forms of social reproduction. Second, it requires broadening our understanding of what constitutes economic activity and therefore which relations need to be considered in trade discourses and trade policy-making. Third, it involves the democratization of global trade relations.

To elaborate, first, as environmental activists have argued, formulating trade policies from the perspective of overarching societal goals rather than from the perspective of economic growth would radically alter their form and content (Klein, 2014). Although global trade institutions generally acknowledge that trade expansion is a means to other societal ends, such as sustainable development, full employment, human rights, the rule of law, democracy, and, increasingly, gender equality, substantial trade rules continue to be formulated from the perspective of trade flows (Trommer, 2016). ${ }^{2}$ They leave intact a status quo in global trade that aims for economic growth through the expansion of merchandise and services trade and investment, irrespective of the negative impacts that this economic model has on the identified overarching societal goals. In terms of gender relations, prioritizing economic growth invariably leads to a line of thinking whereby women's empowerment means bringing the largest possible number of women into the fold of those societal groups that gain directly from increased trade flows: namely, export-oriented corporations and investors. As we have argued, such approaches uphold, and potentially deepen, many of the structural inequalities in which gender inequalities are embedded, rather than actively dismantle them.

\footnotetext{
${ }^{2}$ Where trade rules are formulated to provide for a balancing exercise between trade flows and ulterior societal ends, as under the General Agreement on Tariffs and Trade (GATT) Article XX, they stipulate that those ulterior ends need to be pursued in ways that are least trade-restrictive.
} 
Instead, a feminist global trade politics prioritizes progressive forms of social reproduction as the main purpose of global trade and formulates trade policies from this perspective. This means moving away from a trade regime that confers legal entitlements guaranteed by states to corporations and investors, but only attributes well-intentioned but unenforceable rights to women - and often workers in general - and the environment. To achieve a progressive postneoliberal trade system, we must think seriously about what trade agreements would look like if we were to inscribe the rights of women and other groups that have the potential to be most negatively impacted by trade directly into law, whether at the WTO or through FTAs (Coleman, 2018).

In order to do so, it is essential to re-introduce a conversation about how trade policy can be designed to improve labour standards. These standards must extend beyond the 'formal' productive sphere to include improved conditions in informal and unpaid forms of work areas where women are over-represented globally. Several International Labour Organisation (ILO) conventions would go a long way in this regard if they were enforced in a similar way to trade agreements. Specifically, four conventions set standards for equality of opportunity and treatment at work. They are: ILO Convention number 100 on equal remuneration, number 111 on discrimination in respect of employment and occupation, number 156 on workers with family responsibilities, and number 190 on violence and harassment. Alongside the eight ILO Core Labour Standards, as well as compliance with up-to-date ILO conventions and instruments such as the Forced Labour Protocol and ILO Conventions on health and safety at work, these commitments could be made pre-conditions for entering into trade negotiations.

The European Trade Union Confederation (ETUC)'s set of recommendations for how labour rights can be made effective in trade agreements offers another concrete example of how trade policy can be done differently (ETUC, 2017). We welcome the ETUC's demand that 'every part of trade agreements (such as sections on investment protection or service listing) be consistent with human rights commitments' and full and enforceable dispute settlement be applied to such commitments (ETUC, 2017). We see further need also to include specific institutional commitments to addressing gender-based wage gaps, the precarity of part-time work, informal work and entrepreneurship, and poor labour conditions in areas where women are drawn into exploitative work as part of export-driven growth strategies. At the broadest level, there is a need to address the mismatch between core labour standards and the structural causes that drive women and other vulnerable groups into exploitative work.

A second intricately related move in the repurposing of global trade involves developing and applying a broader understanding of what constitutes economic activity and therefore which relations need to be considered in trade discourses and trade policy-making. Instead of orienting trade discourses and policies around economic indicators, there is a need to consider how trade is underpinned by and works to impact on relations of social reproduction. From this perspective, the main stakeholders in trade policy-making are not only governments and business - as is often taken to be the case - but rather people who engage with trade in their multiple roles as producers, workers, consumers (including consumers of public services), carers, and so on.

Instead of adding stand-alone gender clauses or chapters to existing trade agreements that are otherwise left unchanged, there is a need to (re-)formulate every commitment in trade agreements from the perspective of progressive forms of social reproduction. As noted above, the current practice involves writing clauses that ensure the maximization of trade flows and 
casting the balancing exercise into exceptions clauses, which are required to be applied in the least trade-restrictive way (this occurs across the WTO-covered agreements and FTAs). A more progressive way forward requires that market access and national treatment commitments for goods and services, IPRs, investment clauses, and all other clauses in agreements are written in ways that balance the goal of enabling global trade flows with other societal goals. If gender concerns are written into trade rules in this way, it would also resolve the shortcoming that gender chapters are not enforceable at present.

It is further crucial that trade institutions give effect to the Beijing Platform for Action currently the only international legal instrument on gender equality that addresses global trade relations directly. It asks governments to 'enable women to gain access to full and equal participation in the formulation of policies and definition of structures through such bodies as ministries of finance and trade, national economic commissions, economic research institutes and other key agencies, as well as through their participation in appropriate international bodies' (Article 165.d). It further states that they must 'seek to ensure that national policies related to international and regional trade agreements do not have an adverse impact on women's new and traditional economic activities' (Article 165.k). The Beijing Platform also counts unremunerated, family and community work as part of economic activity and acknowledges that economic activity can be carried out in formal or informal, protected and poorly or unprotected, domestic or migrant settings across production, service delivery, subsistence agriculture and entrepreneurship.

In order to meet the requirements of the Beijing Platform, there is a need to engage in much more robust impact assessment and monitoring. In existing human rights impact assessments of trade policy, 'some impacts that would undoubtedly be considered serious from a human rights perspective do seem to be apparent', but they remain unidentified or are viewed as insignificant in reports commissioned, compiled and consumed from the dominant trade perspective (Harrison and Goller, 2008: 599). The central purpose of ex ante and ex post impact assessments has to be to inform trade policy-making, rather than to legitimate trade policy choices in the public debate, as is currently the case. There are a number of progressive methodologies that could form the basis of a comprehensive gender-based impact assessment framework, including the UNCTAD toolbox, as well as proposals made by other UN agencies (e.g. UNEP, 2001) and in the scholarship (e.g. Fontana, 2016; Walker, 2005). In our view, there is a need to go even further than many of these suggestions.

As we have elaborated elsewhere (Hannah, Roberts and Trommer, 2018), gender-based impact assessments can contribute to a progressive, feminist post-neoliberal trade system if they are based on several key principles. For one, all parties to an agreement must assess the broader context, undertaking a broad survey before beginning gender-impact modelling in order to understand how existing gender norms and power relations shape forms of economic participation at multiple sites and scales within the territories entering into the agreement. Gendered computable general equilibrium modelling may be helpful in predicting the effects of a proposed trade agreement on men and women in their various roles (Fontanta, 2004) if they make use of existing feminist methodologies such as Social Accountability Matrices and model-varying degrees of liberalisation. Additional, qualitative modes of inquiry are required to capture changes in the quality of employment, control over resources, and the effects of rules governing investment protections, IPRs, procurement, and more. These methods include engagement with women's groups and civil society actors in the areas under investigation. 
This brings us to the third interrelated move that is necessary for a more equitable postneoliberal trading system. This entails the democratization of trade policy-making, which requires that we take seriously the voices of women's groups, trade unions and civil society organizations. The dominant model at present for civil society inclusion in trade policymaking is de facto a one-way street where informal advocacy channels are largely closed to non-business civil-society groups and where policy elites consider the ideas and knowledge about global trade that non-business civil-society groups provide to be ill-informed about the workings of the global economy (Hannah, 2016; Hannah, Scott and Trommer, 2015). As our discussion has made clear, global trade affects people in their multiple roles and representatives of different groups of people and sectors of society have to have a say when trade-policy choices are made.

In order to make civil-society representation in global trade decision-making effective, three governance trends of the past decade have to be reversed. First, the shift towards FTAs as preferred trade governance venues has undermined many of the transparency and accountability gains made at the WTO following the 1999 Seattle protests. In particular, socalled 'mega-regionals' and ' 21 st century trade agreements', which contain many of the problematic rules on services, IP, investment and government procurement, have been carried out with virtually no access to information outside of trade ministries.

Second, diversity in civil-society representation has been lost in core countries due to funding cuts in the austerity era, and in particular when it comes to women's groups' engagement in trade advocacy (Macdonald, Ibrahim and Sinclair, 2018). These groups bring not only important knowledge about how trade affects women's (and other minorities') lives to the attention of trade policy-makers, but their knowledge about the global trade system can bridge the divide between trade-policy circles and the broader public, which often sees trade policy as technocratic, complex and abstract.

Third, and in contrast with the inclusion of civil-society representation in the failed International Trade Organisation charter negotiated in the 1940s, the view that direct and formal involvement of civil-society groups in the work of trade institutions is 'not possible' has been further entrenched among policy-makers in the embedded liberal and neoliberal eras (WTO, 1996). While dominant trade institutions by and large continue to subscribe to the view that civil society has a second-order role to play at best (Hannah, Janzwood, Scott and Wilkinson, 2018), there are examples of more inclusive and participatory models at the fringes of the global economy. In Sub-Saharan Africa, South Africa's tripartite model of trade policy-making and the Economic Community of West African States' participatory model for negotiating its Economic Partnership Agreement with the EU stand as concrete examples (Trommer, 2014). In the United Kingdom, the House of Commons International Trade Committee outlined its policy on transparency and scrutiny in December 2018 (House of Commons International Trade Committee, 2018). The report highlights the important role for business and civil society and for parliamentary oversight in trade policy-making and implementation.

This article has set out a project of reform that we believe to be necessary in order to build a feminist post-neoliberal trading system. We have suggested that, if trade policy is to be used as a means of achieving gender equality, it must be designed in a way that addresses structural inequalities. Reforming the rules of global trade in ways that afford states greater domestic policy space is not sufficient in this regard, as the state may itself work to reproduce inequalities. There is therefore a need for a more thorough shift in macroeconomic policy- 
making at the national and global levels so that structural inequalities are redressed and progressive forms of social reproduction prioritized above economic growth, which is currently 'locked in' to trade agreements and global institutions. Second, creating a more gender-equitable trading system requires looking beyond economic indicators to consider the ways in which relations of social reproduction underpin and are impacted by trade. This means that trade policy-makers need to have a holistic understanding of what constitutes the economy and consider the impacts of trade on households, care work, unpaid labour, the informal economy, and the broader ecological conditions under which social reproduction takes place. Finally, we need to democratize governance structures. This means not only widening the scope of social and political actors who meaningfully participate in trade policy-making, but also widening the scope of ideas and lived experiences that count as legitimate trade concerns. While we have pointed to a number of concrete steps that can and should be taken in support of these objectives, we must also remain open about the direction of change if we are to take the principle of democratic decision-making seriously.

\section{References}

Azevdo, R. (2019). Global cooperation on digital economy vital to unlock trade benefits for women. Speech at the WTO Workshop on Digital Trade and Gender, 1 July. Available at: https://www.wto.org/english/news_e/spra_e/spra268_e.htm

Bakker, I. \& Gill, S. (2006). New constitutionalism and the social reproduction of caring institutions. Theoretical Medicine and Bioethics, 27(1), 35-57.

\section{Balakrishnan, R. \& Elson, D. (2011). Economic policy and human rights: Holding} governments to account. London: Zed Books.

Bedford, K. \& Rai, S. (2010). Feminists Theorize International Political Economy. Signs: Journal of Women in Culture and Society, 36(1) [Special Issue].

Bishop, M. \& Payne, A. (2019). Reglobalisation in action - Part 1: Rehearsing the concept. SPERI.Comment: the Political Economy Blog, 15 October. Available at: http://speri.dept.shef.ac.uk/2019/10/15/reglobalisation-in-action-part-1-rehearsing-theconcept/

Bishop, M. L. \& Payne, A. (2020). The Political Economies of Different Globalizations: Reembedding Post-neoliberal Reglobalization? Globalizations, TBC.

Bissio, R. (2017). Is 'Gender' a Trojan Horse to Introduce New Issues at WTO?. Third World Network, 11 December. Available at:

https://twnetwork.org/wto/\%E2\%80\%9Cgender\%E2\%80\%9D-trojan-horse-introduce-newissues-wto

Busse, M. \& Spielmann, C. (2006). Gender inequality and trade. Review of International Economics, 14(3), 362-379

Coleman, L. M. (2018). Global social fascism: Violence, law and twenty-first century plunder, CGPE Working Paper, University of Sussex. Available at: 
https://www.sussex.ac.uk/webteam/gateway/file.php?name=global-social-fascism-wp15coleman-montesinos.pdf\&site $=359$

Eagleton-Pierce, M. (2016). Neoliberalism: The key concepts. Abingdon: Routledge.

Edholm, F., Harris, O. \& Young, K. (1977). Conceptualising women. Critique of Anthropology, 3 (9 \& 10), 101-130.

Elias, J. \& Roberts, A. (eds.) (2018) Handbook on the International Political Economy of Gender. Cheltenham: Edward Elgar.

Elson, D., Grown, C. \& Cağatay, N. (2007). Mainstream, heterodox and feminist trade theory. In van Staveren et al. (eds.), The feminist economics of trade. London: Routledge. pp. 33-52.

European Commission (2018) Draft provisions on Trade and Gender Equality in the context of the Modernisation of the EU-Chile Association Agreement, 22 June. Available at https://trade.ec.europa.eu/doclib/docs/2018/june/tradoc_156962.pdf

European Commission (2019) Trade Sustainability Impact Assessment in Support of FTA Negotiations between the European Union and New Zealand, Draft Inception Report.

Available at: http://trade-sia-new-zealand.eu/images/reports/EUNZ_SIA_Draft_Inception_Report.pdf

ETUC (2017). ETUC Submission on the Non-paper of the Commission Services and Trade and Sustainable Development (TSD) Chapters in EU Free Trade Agreements (FTA). Available at: https://www.etuc.org/en/document/etuc-submission-non-paper-commissionservices-trade-and-sustainable-development-tsd

Ferber, M. A. \& Nelson, J. A. (1993). Beyond economic man: Feminist theory and economics. Chicago IL: The University of Chicago Press.

Folbre, N. (2001). The invisible heart: Economics and family values. New York NY: The New Press.

Fontana, M. (2004). Modelling the effects of trade on women, at work and at home: Comparative perspectives. Economie Internationale 3(99), 49-80.

Fontana, M. (2016). Gender equality in trade agreements. Study Commissioned by the Policy Department for Citizen's Rights and Constitutional Affairs. Brussels: European Union.

Fraser, N. (2014). Can societies be commodities all the way down?: Post-Polanyian reflections on capitalist crisis. Economy and Society, 43(4), 541-558.

Gender \& Development Network. (2017). Making trade work for gender equality. Available at: https://gadnetwork.org/gadn-resources/2017/7/4/making-trade-work-for-gender-equality-1

George, C. (2015). Numbers: The role of computable general equilibrium modeling in legitimizing trade policy. In Hannah, E., Scott, S. \& Trommer, S. (Eds), Expert knowledge in global trade. Abingdon: Routledge. pp. 107-23. 
Global Affairs Canada. (2019). Summary of initial gender-based analysis plus for CanadaMercosur free trade agreement negotiations. Available at:

https://www.international.gc.ca/trade-commerce/assets/pdfs/gba plus_summaryacs plus resume eng.pdf

Government of Canada. (2018). Gender-based analysis plus. Available at: https://cfcswc.gc.ca/gba-acs/approach-approche-en.html

Hannah, E. (2016). NGOs and global trade: Non-state voices in EU trade policymaking. London: Routledge.

Hannah, E., Roberts, A. \& Trommer, S. (2018). Gendering global trade governance through Canada-UK trade relations. Knowledge synthesis grant: Final report. Available at: https://www.kings.uwo.ca/kings/assets/File/academics/polisci/bios/hannah/KSG-FinalReport.pdf

Hannah, E., Scott, J. \& Trommer, S. (2015). Expert knowledge in global trade. Abingdon: Routledge.

Hannah, E., Scott, J. \& Wilkinson, R. (2018). The WTO in Buenos Aires: The outcome and its significance for the future of the multilateral trading system. World Economy 41(10), 2578-98.

Hannah, E., Janzwood, A., Scott, J. \& Wilkinson, R. (2018). What kind of civil society? The changing complexion of public engagement at the WTO. Journal of World Trade 52(1), 113141.

Harrison, J. \& A. Goller (2008). Trade and human rights: What does 'impact assessment' have to offer? Human Rights Law Review, 8(4), 587-615.

Hoskyns, C. \& Rai, S. M. (2007). Recasting the global political economy: Counting women's unpaid work. New Political Economy, 12(3), 297-317.

House of Commons International Trade Committee. (2018). UK trade policy transparency and scrutiny. Sixth report of session 2017-2019. HC 1043. London: House of Commons.

ITC. (2017). New pathways to e-commerce: A global MSMEs competitiveness survey. Available at:

http://www.intracen.org/uploadedFiles/intracenorg/Content/Publications/New\%20Pathways $\% 20$ to $\% 20$ E-commerce_Low $\% 20$ res(2).pdf

Jamali, D. (2009). Constraints and opportunities facing women entrepreneurs in developing countries: A relational perspective. Gender in Management: An International Journal 24(4), 232- 251.

James, D. (2019). Anti-development impacts of tax-related provisions in proposed rules on digital trade in the WTO. Development 62(1-4), 58-65. 
Kelsey, J. (2017). Gender 'Pinkwashing' at the WTO bodes ill. Scoop Independent News, 13 December. Available at: http://www.scoop.co.nz/stories/PO1712/S00117/genderpinkwashing-at-the-wto-bodes-ill.htm

Klein, N. (2014). This changes everything: Capitalism vs the climate. New York NY: Simon $\&$ Schuster.

Larouche-Maltais, A. \& MacLaren, B. (2019). Making gender responsive free trade agreements. Ottawa: Conference Board of Canada.

Luxton, M. (2006). Feminist political economy in Canada and the politics of social reproduction. In Bezanson, K. \& Luxton, M. (eds.). Social reproduction: Feminist political economy challenges neo-liberalism. Montreal; Kingston: Queens University Press. pp. 11-44.

Luxton, M. (2018). The Production of life itself: Gender, social reproduction and IPE. In Elias, J. \& Roberts, A. (eds.). Handbook on the international political economy of gender. Cheltenham: Edward Elgar. pp. 37-49.

Macdonald, L., Ibrahim N. \& Sinclair, S. (2018). Gender, trade and austerity. The Monitor, Canadian Centre for Policy Alternatives. July-August, 38-39.

Mlumbi-Peter, X. (2019). Speaking on the panel 'What do women need? WTO reform for a comprehensive gender-friendly trading system', WTO Public Forum, 10 October. Geneva: World Trade Organization.

Monteiro, J.-A. (2018). Gender-related provisions in regional trade agreements. Staff Working Paper ERSD-2018-15. Geneva: World Trade Organization

Muzaka, V. \& Bishop, M. (2015). Doha stalemate: The end of trade multilateralism? Review of International Studies, 41(2), 383-406.

OHCHR (2015). UN experts voice concern over adverse impact of free trade and investment agreements on human rights. Available at:

https://ohchr.org/EN/NewsEvents/Pages/DisplayNews.aspx?NewsID=16031

Our World is Not for Sale. (2017). Women's rights groups call on governments to reject the WTO Declaration on Women's Economic Empowerment. 13 December. Available at: http://ourworldisnotforsale.net/2017/Feminist_stmt.pdf

Polanyi, K. (1944). The great transformation: The political and economic origins of our time. Boston MA: Beacon Press.

Prügl, E. \& True, J. (2014). Equality means business? Governing gender through transnational public-private partnerships. Review of International Political Economy, 21(6), 1137-1169.

Rai, S. M. \& Waylen, G. (eds.). (2014). New frontiers in feminist political economy. London: Routledge. 
Roberts, A., Trommer, S., \& Hannah, E. (2019). Gender impacts of trade and investment agreements. Policy briefing prepared for the UK Women's Budget Group. Available at: https://wbg.org.uk/analysis/uk-policy-briefings/gender-impacts-of-trade-and-investmentagreements/

Roberts, A. \& Zulfiqar, G. (2019). The Political Economy of Women's Entrepreneurship Initiatives in Pakistan: Reflections on Gender, Class, and 'Development'. Review of International Political Economy, 26(3), 410-435.

Rodrik, D. (2011). The globalization paradox: Democracy and the future of the world economy. New York NY: WW Norton \& Company.

Ruggie, J. G. (1982). International regimes, transactions and change: Embedded liberalism in the postwar economic order. International Organization, 36(2), 379-415.

Siddiqui, R. (2009). Modeling gender effects of Pakistan's trade liberalization. Feminist Economics 15(3), 287-321;

Trommer, S. (2016). Trade policy communities, expert language and the de-humanization of world trade. In Hannah, E., J. Scott \& S. Trommer. (Eds.). Expert knowledge in global trade. Abingdon: Routledge. pp. 63-82.

Trommer, S. (2014). Transformations in trade politics: Participatory trade politics in West Africa. Abingdon: Routledge.

UNCTAD (2017). Trade and gender toolbox: How will the Economic Partnership Agreement between the European Union and the East African Community affect Kenyan women?. Geneva: UNCTAD.

UNEP (2001). Reference manual for the integrated assessment of trade-related policies. New York NY: United Nations.

van Staveren, I., Elson, C. G. \& Çağatay, N. (eds.). (2007). The feminist economics of trade. London: Routledge

Vita, L. D., Mari, M. \& Poggesi, S. (2014). Women Entrepreneurs in and from Developing Countries: Evidence from the Literature. European Management Journal 32(3), 451- 460.

Walker, S. (2005). Human rights impact assessments of trade-related policies. In Gehring, M. \& Segger, M.-C. (Eds), Sustainable Development in World Trade Law. The Hague: Kluwer Law International. pp. 217-56.

Williams, M. (2007). Gender issues in the multilateral trading system', van Staveren, I., Elson, C. G. \& Çağatay, N. (eds.). (2007). The feminist economics of trade. London: Routledge. pp. 277-91.

Williams, M. (2013). A Perspective on Feminist International Organizing from the Bottom Up: The Case of the ITGN and the WTO. In Caglar, G., Prugl, E. \& Zwingel, S. (Eds), Feminist Strategies in International Governance. Abingdon: Routledge. pp. 92-108. 
Williams, M. (2019). Speaking on the panel "What do women need? WTO reform for a comprehensive gender-friendly trading system", WTO Public Forum, 10 October, Geneva: World Trade Organization.

WTO and OECD (2019). Aid for Trade at a glance 2019: Supporting economic diversification and empowerment. Available at: https://www.oecd.org/dac/aft/aid-for-tradeat-a-glance-22234411.htm

WTO (1996). Guidelines for arrangements on relations with non-governmental organizations. WT/L/162. Geneva: World Trade Organization.

WTO (2017). Joint declaration on trade and women's economic empowerment on the occasion of the WTO Ministerial Conference in Buenos Aires in December 2017. Available at: https://www.wto.org/english/thewto_e/minist_e/mc11_e/genderdeclarationmc11_e.pdf 